$B$

J. bio-sci. 15: 35-40, 2007

ISSN 1023-8654

http://www.banglajol.info/index.php/JBS/index

\title{
EFFECT OF INTERCROPPING OF MUSTARD WITH ONION AND GARLIC ON APHID POPULATION AND YIELD
}

\author{
P K Sarker, M M Rahman and B C Das ${ }^{1}$
}

Department of Zoology, University of Rajshahi, Rajshahi-6205, Bangladesh

\begin{abstract}
Field experiments were conducted to study the effect of intercropping of mustard (Brassica napus. Var. Bari Sarisha-7) with onion (Allium cepa L.) and garlic (Allium sativum L.) on aphid [Lipaphis erysimi (Kaltenbach)] population and yield. Intercropped with these two medicinal as well as spice crops reduced the aphid population significantly $(P<0.05)$. Mustard blocks intercropped with garlic gave highest cost-benefit ratios (1:2.07 and 1: 2.96) than onion intercropped blocks. Sole mustard blocks produced lowest cost-benefit ratios (1:1.65 and 1:2.06).
\end{abstract}

Key words: Intercropping, onion, garlic, agronomic benefits.

\section{Introduction}

Intercropping is an ancient and traditional agronomic practice which, if utilized correctly, can contribute significantly to reduce pest problems. Intercropping can be explained as a system where two or more crop species are grown in the same field at the same time during a growing season (Ofori and Stern 1987). It is a simple and inexpensive strategy and has been recognized as a potentially befitted technology to increase crop production due to its substantial yield advantage than sole cropping (Awal et al. 2006). The purpose of intercropping is to generate beneficial biological interactions between the crops. Intercropping can increase yields, more efficiently use available resources, reduce weed, insect and disease pressures and provide greater biological and economic stability (Vandermeer 1989). Intercropping has been an essential production method in tropical regions for hundreds of years (Vandermeer 1989), and to a lesser extent in temperate regions (Li et al. 2001). Intercropping was once common in temperate regions, but has been largely replaced in the last 150 years by monocultures (Francis 1986).

Mustard is the principal edible oilseed crop in Bangladesh. It is infested by a number of pests, out of which mustard aphid, Lipaphis erysimi (Kaltenbach) (Homoptera: Aphididae) is the most destructive one (Das 2002). Several field trials on mustard have been conducted till to date using different intercrops such as banana (Rahman et al. 2006); barley (Gangasaran and Giri 1985); bean (Morse et al. 1997); cabbage (Bender et al. 1999); chickpea (Gangasaran and Giri 1985, Samsuzzaman et al. 1995, Singh and Rathi 2003); chilli (Mamun et al. 2002); coriander (Sing and Kothari 1997); gram (Jana et al. 1995, Bohra et al. 1999, Banik et al. 2000, Tahir et al. 2003); groundnut (Dhyani and Tripathi 1999); linseed (Tahir et al. 2003); lentil (Gangasaran and Giri 1985, Jana et al. 1995, Banik et al. 2000 Tahir et al. 2003); oat (Morse et al. 1997); Pea (Banik et al. 2000); wheat (Zahid et al. 2002 Tahir et al. 2003) etc. and found lower aphid infestation on different intercropped plant than sole crops (Nampala et al. 2002, Ma et al. 2006). However, no information is available on onion (Allium cepa L.) and garlic (Allium sativum L.) intercropped with mustard. In

${ }^{1}$ Corresponding author, email: bcdzool@yahoo.com 
fact, very little works have been done on relay intercropping of mustard with other semi season crops in Bangladesh (Samsuzzaman et al. 1995, Mamun et al. 2002). Hence, the present study was undertaken to find out the effect of intercropping on aphid abundance, yield of mustard crops and total agronomic benefits using onion and garlic plants.

\section{Materials and Methods}

Experimental design: Field trials were conducted during the winter season of 2005-2006 and 2006-2007 in the research field of Zoology Department, Rajshahi University Campus. Mustard (Brassica napus var. Bari Sarisha-7) with local varieties of onion (A. cepa) and garlic (A. sativum) were selected for intercropping. Altogether 9 blocks (each 1 sq. meter) were prepared and 3 replications for each category [onion+mustard, garlic+mustard and mustard (sole)] were taken for this experiment. Equal amount of fertilizer (as used in mustard as suggested by BARI) (Mondol and Wahhab 2001) was used and two times irrigation (as need) were done in the field. Mustard seeds sown in the blocks randomly and the onion (seed bulb) and garlic (clove) were planted in rows. Distance of sowing (onion and garlic) was maintained as: $30 \mathrm{~cm}$ from line to line (4 lines in each plot) and $10 \mathrm{~cm}$ from plant to plant (11 plants in each line). After germination, mustard plants which were very close to onion and garlic plants were uprooted.

Counting of the aphids: Mustard plants were checked regularly for aphids. Whole plants were selected for aphid counting. Aphids were counted weekly through eye estimation without disturbing the colony. Counting was made from the onset of aphid infe station till their disappearance or harvesting of the crops.

Yield assessment: Harvested mustard seed, onion and garlic were weighed and estimated their prices in local markets to calculate the effect of intercropping and cost benefit ratio among sole and intercropped blocks.

Data analysis: Analysis of variance (ANOVA) was carried out to test the significant difference of aphid population among intercropped and sole mustard blocks. Comparison of means was undertaken using Duncan's Multiple Range Test (DMRT). The gross returns of sole and intercropped blocks were tested by ANOVA and ranked by DMRT.

\section{Result and Discussion}

The weekly aphid populations of nine blocks for two consecutive years (2005-2006 and 2006-2007) are shown in Figures 1 and 2. From the figure it is observed that the aphid population in onion and garlic intercropped blocks were significantly low $(\mathrm{P}<0.05)$ as compared to non intercropped blocks for both the years.

Yields of all three crops (intercropped and sole) of two seasons are given in Table 1 and found that total mustard equivalents are higher in garlic followed by mustard intercropped plot and sole mustard plot shows lowest yield. Yield equivalent (T/h.), Variable cost (Tk/h.) and the cost benefit ratios of aforesaid two seasons are given in Table 2. From the table it appears that cost benefit ratios of intercropped blocks show higher values than that of sole mustard crop for both the years. Mustard blocks intercropped with garlic shows highest cost benefit ratios (1:2.07 and 1:2.96) than onion intercropped blocks. Sole mustard blocks indicate lowest cost benefit ratios (1:1.65 and 1:2.06). 


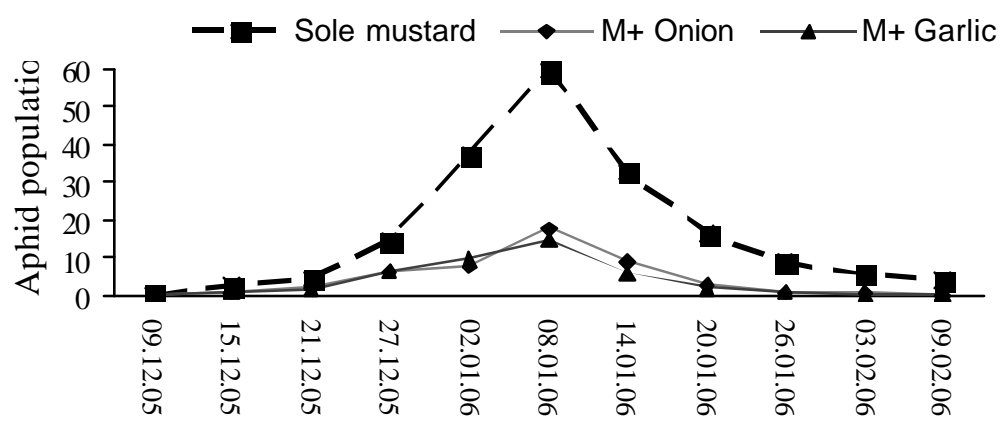

Figure 1. Aphid population of mustard with two intercropped and sole mustard blocks for the season 2005-2006 ( $\mathrm{P}=0.05)$

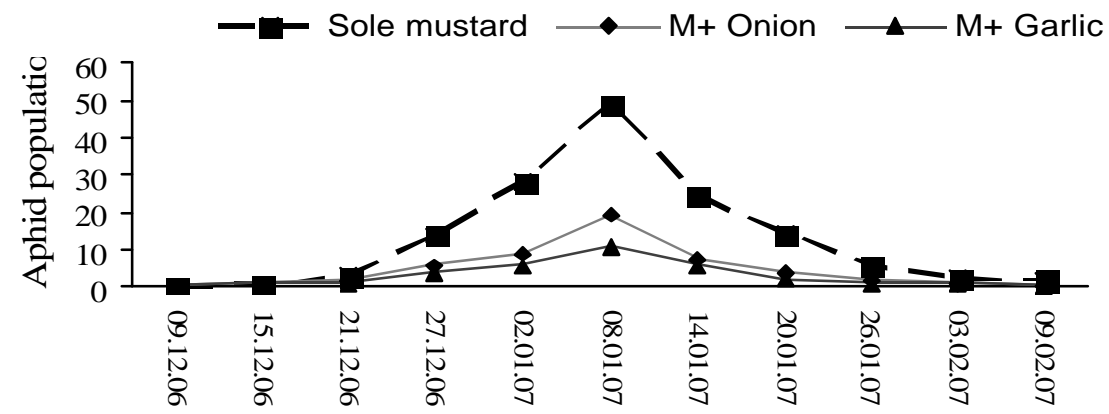

Figure 2. Aphid population of mustard with two intercropped and sole mustard blocks for the season 2006-2007 ( $\mathrm{P}=0.05)$

Table 1. Yield of mustard, onion and garlic for the season 2005-2006 and 2006-2007.

\begin{tabular}{|ccccccc|}
\hline \multirow{2}{*}{ Season } & Treatment/ & \multicolumn{3}{c}{ Yield per plot (kg/plot) } & $\begin{array}{c}\text { Totals } \\
\text { (mustard } \\
\text { equivalent) }\end{array}$ \\
\cline { 3 - 4 } $2005-06$ & Mustard & Onion & Garlic & & 0.190 \\
& Mustard+ onion & 0.116 & 0.115 & - & 0.199 \\
& Mustard+ garlic & 0.119 & - & 0.050 & 0.161 \\
& Sole mustard & 0.161 & - & - & 0.224 \\
\multirow{2}{*}{$2006-07$} & Mustard+ onion & 0.118 & 0.166 & - & 0.233 \\
& Mustard+ garlic & 0.118 & - & 0.072 & 0.193 \\
\hline
\end{tabular}


Table 2. Gross return (Tk/hectare), variable cost and cost benefit ratio for sole mustard and intercropped with onion and garlic plants for the season 2005-2006 and 2006-2007.

\begin{tabular}{|c|c|c|c|c|c|c|c|c|}
\hline \multirow{2}{*}{$\begin{array}{l}\overline{0} \\
\text { đ్ } \\
\text { ஸ }\end{array}$} & \multirow{2}{*}{$\begin{array}{l}\text { Treatment/ } \\
\text { Combination }\end{array}$} & \multicolumn{4}{|c|}{ Gross return per plot (Tk/hectare) } & \multirow{2}{*}{$\begin{array}{c}\text { Variable cost } \\
\text { (Tk/h.) }\end{array}$} & \multirow{2}{*}{$\begin{array}{c}\text { Net return } \\
\text { (Tk/h) }\end{array}$} & \multirow{2}{*}{$\begin{array}{c}\text { Cost } \\
\text { benefit } \\
\text { ratio }\end{array}$} \\
\hline & & Mustard & Onion & Garlic & Total* & & & \\
\hline \multirow{3}{*}{$\begin{array}{l}8 \\
\text { ò } \\
\text { ம் }\end{array}$} & Mustard+ onion & 28980.00 & 18515.00 & - & $47495.00 \mathrm{~b}$ & 16269.47 & 31225.53 & 1:1.92 \\
\hline & Mustard+ garlic & 29785.00 & - & 20125.00 & $49910.00 \mathrm{a}$ & 16269.47 & 33640.53 & 1:2.07 \\
\hline & Sole mustard & 40250.00 & - & - & $40250.00 c$ & 15184.84 & 25065.16 & 1:1.65 \\
\hline \multirow{3}{*}{$\begin{array}{l}\text { ợ } \\
\text { o̊ }\end{array}$} & Mustard+ onion & 35420.00 & 26565.00 & - & $61985.00 \mathrm{~b}$ & 16269.47 & 45715.53 & 1:2.81 \\
\hline & Mustard+ garlic & 35420.00 & - & 28980.00 & $64400.00 \mathrm{a}$ & 16269.47 & 48130.53 & $1: 2.96$ \\
\hline & Sole mustard & 48300.00 & - & - & $48300.00 c$ & 15761.05 & 32538.95 & 1:2.06 \\
\hline
\end{tabular}

*Means followed by same letter had no significant difference at $p<0.05$ by DMRT.

Intercropping system can be practiced to get more agronomic advantages. Simmonds et al. (1992) reported that Alium spp. are very effective antifeedant and Kirtikar and Basu (1975) reported that Alium spp. have strong pungent repelling action. Singh and Kothari (1997) compared aphid infestation on monocrop mustard ('Rohini') with intercrop teatments of artemisia (Artemisia annua L.), coriander (Coriandrum sativum L.), chamomile (Matricaria chamomilla L.), fennel (Foeniculum vulgare Mill.) and dill (Anethum sowa Kurz.) and found that fennel intercropped resulted in significantly lower aphid population.

Mamun et al., (2002) intercropped mustard with chilli at different seedling ratios and got higher yield and profit in seedling ratio as: $26 \%$ mustard $+100 \%$ chilli. Samsuzzaman et al. (1995) evaluated the performance of mustard and chickpea (Cicer arietinum) intercropping at different levels and got best results considering yield and economic returns from mustard 75\%+chickpea 25\% among other combinations. Wnuk (1998) found that intercropping of pea with tansy phacelia and white mustard had significant effect of decreasing the pea thrips population; however the author got a reverse result of intercropping for the pests, pea aphid, pea moth, and pea beetle. Singh and Rathi (2003) got higher productivity for intercropping of chickpea and mustard in the 4: 1 row ratio than for sowing of chickpea and mustard in sole stands in terms of land equivalent ratio. Tahir et al. (2003) concluded after their experiment that canola was the dominant crop in each intercropping system, and wheat was more competitive followed by linseed than gram and lentils.

Bohra et al. (1999) studied the intercropping system of gram and mustard in different ratios and found all the intercropping treatments recorded yield advantage over sole cropping of mustard and gram. Jana et al. (1995) intercropped mustard with gram and lentil and found that all intercropping treatments of mustard + gram were better in relative crowding coefficient, land-equivalent ratio, monetary advantage, relative net return, area-time equivalent ratio and relative value total, giving greater productivity/unit land than monocultures. From the present result it may be concluded that mustard could be grown with onion and garlic as standard intercropping to get more economic benefit and avoid aphid infestation up to economic threshold level. 


\section{Acknowledgements}

Thanks are due to the Chairman, Department of Zoology, Rajshahi University, Rajshahi-6205, Bangladesh for providing field and laboratory facilities.

\section{References}

Awal M A, Kothi H and Ikeda T (2006) Radiation interception and use by maize/peanut intercrop canopy. Agric. For. Meteorol. 139:73-84.

Banik P, Sasmal T, Ghosal P K and Bagchi D K (2000) Evaluation of mustard (Brassica compestris Var. Toria) and legume intercropping under 1:1 and 2:1 row -replacement series systems. J. Agronomy \& Crop Science 185: 9-14.

Bender D A, Morrison W P and Frisbie R E (1999) Intercropping cabbage and Indian mustard for potential control of lepidopterous and other insects. Hort. Science 34(2): 206-209.

Bohra J S, Goswami A and Sah D (1999) Agronomic studies on gram and mustard intercropping. 10 International Rapeseed Congress, Australia.

Das B C (2002) Ecology and diversity of agricultural crop infesting aphids (Homoptera: Aphididae) in Bangladesh. J. Aphidol. 16: 51-57.

Dhyani S K and Tripathi R S (1999) Tree growth and crop yield under agrisilvicultural practices in northeast India. Agroforestry Systems 44: 1-12.

Francis C A (1986) Multiple cropping systems. Macmillan Publ. Co, New York pp. 383.

Gangasaran and Giri G (1985) Intercropping of mustard with chickpea, lentil and barley in drylands. Indian J. Agron. 30(2): 244-250.

Jana P K, Mandal B K, Prakash O M and Chakraborty D (1995) Growth, water use and yield of Indian mustard (Brassica juncea), gram (Cicer arietinum) and lentil (Lens culinaris) grown as sole crops and intercrops with three moisture regimes. Indian J. Agric. Sci. 65(6): 387-393.

Kirtikar K R and Basu B D (1975) Indian medicinal plants (2 ${ }^{\text {nd }}$ ed.) vol. II M/S. Bishen Sing, Mahendra Pal Sing, New Connaught Place, Dehra Dun, D-42, Vivek Vihar, Delhi, 1225-1227pp.

Li L, Sun J, Zhang F, Li X, Yang S, and Rengel Z (2001) Wheat/maize or wheat/soybean strip intercropping I. Yield advantage and interspecific interactions on nutrients. Field Crops Res. 71: 123-137

Ma X M, Liu X X, Zhang Q W, Zhao J Z, Cai Q N, Ma Y A and Chen D M (2006) Assessment of cotton aphids, Aphis gossypii, and their natural enemies on aphid-resistant and aphid-susceptible wheat varieties in a wheat-cotton relay intercropping system. Ent. exp. appl. 121: 235-241

Mamun A N M, Choudhury D A, Ibrahim M, Hossain M A and Kabir A H M F (2002) Performance of chilli as intercropped with mustard. Pak. J. Biol. Sci. 5(9): 909-910.

Mondal R I and Wahhab A (2001) Production technology of oil crops. Oilseed Research Centre, BARI, Bangladesh: 1-111.

Morse S, Willey R W and Nasir M (1997) Modelling the long-term yield effects of compensation in intercropping using data from a field experiment. Expl Agric. 33: 291-299.

Nampala P, Ogenga-Latigo M W, Kyamanywa S, Adipala E, Oyoba N and Jackai L E N (2002) Potential impact of intercropping on major cowpea field pests in Uganda. Afr. Crop Sci. J. 10(4): 335-344. 
Ofori F and Stern W R (1987) Cereal-legume intercropping systems. Adv. Agron. 41: 41-90.

Rahman M Z, Rahman M H, Haque M E, Kabir M H, Naher S L, Ferdous K M K B, Huda A K M N, Imran M S and Khalequzzaman M (2006) Banana based intercropping system in north-west part of Bangladesh. J. Agron. 5(2): 228-231.

Samsuzzaman S, Karim M M A, Ali M A and Mohiuddin M (1995) Performance of mustard (Brassica juncea) and chickpea (Cicer arietinum) intercropping at varying levels of population in the farmers' field. J. bio-Sci. 3:171-176.

Simmonds M S J, Evans H C and Blaney W M (1992) Pesticide for the year 2000. Mycochemical and Botanicals, pp. 127-164. In: Kadir AA SA and Barolv H S (eds.) Pest management and environment in 2000. CAB International Wallingford, Oxon, UK.

Singh K K and Rathi K S (2003) Dry matter production and productivity as influenced by staggered sowing of mustard intercropped at different row ratios with chickpea. J. Agron. Crop Sci. 189:169-175.

Singh D and Kothari S K (1997) Intercropping effects on mustard aphid (Lipaphis erysimi) populations. Crop Sci. 37(4): 1263-1264.

Tahir M, Malik M A, Tanveer A and Rashid A (2003) Competition functions of different canola based intercropping systems. Asian J. Plant Sci. 2(1): 9-11.

Vandermeer J (1989) The ecology of intercropping. Cambridge University Press, Great Britain pp.237.

Wnuk A (1998) Effect of intercropping of pea with tansy phacelia and white mustard on occurrence of pests. Folia Horticulture 10(1): 67-74.

Zahid M S, Shafeeq S and Mufti M U (2002) Mix cropping of mustard and wheat in Fatehjang Tehsil. Pakistan J. Agr. Res. Abstracts: April-June, 2002. 